\title{
Tritium Aging Effects in Palladium on Kieselguhr
}

$$
\text { CONF-981037-- }
$$

by

K. L. Shanahan

Westinghouse Savannah River Company

Savannah River Site

Aiken, South Carolina 29808

J. S. Holder

J. R. Wermer

A document prepared for INTERNATIONAL SYMPOSIUM ON METAL HYDROGEN SYSTEMS FUNDAMENTALS AND APPLICATIONS at Hangzhou, , China from 10/4/98 - 10/9/98.

DOE Contract No. DE-AC09-96SR18500

This paper was prepared in connection with work done under the above contract number with the U.S. Department of Energy. By acceptance of this paper, the publisher and/or recipient acknowledges the U. S. Government's right to retain a nonexclusive, royalty-free license in and to any copyright covering this paper, along with the right to reproduce and to authorize others to reproduce all or part of the copyrighted paper. 


\section{DISCLAIMER}

This report was prepared as an account of work sponsored by an agency of the United States Government. Neither the United States Government nor any agency thereof, nor any of their employees, makes any warranty, express or implied, or assumes any legal liability or responsibility for the accuracy, completeness, or usefulness of any information, apparatus, product, or process disclosed, or represents that its use would not infringe privately owned rights. Reference herein to any specific commercial product, process, or service by trade name, trademark, manufacturer, or otherwise does not necessarily constitute or imply its endorsement, recommendation, or favoring by the United States Government or any agency thereof. The views and opinions of authors expressed herein do not necessarily state or reflect those of the United States Government or any agency thereof.

This report has been reproduced directly from the best available copy.

Available to DOE and DOE contractors from the Office of Scientific and Technical Information, P. O. Box 62, Oak Ridge, TN 37831; prices available from (423) 576-8401.

Available to the public from the National Technical Information Service, U. S. Department of Commerce, 5285. Port Royal Road, Springfield, VA 22161. 


\section{DISCLAIMER}

Portions of this document may be illegible electronic image products. Images are produced from the best available original document. 


\title{
Tritium Aging Effects in Palladium on Kieselguhr (U)
}

\author{
Kirk L. Shanahan, J. S. Holder, J. R. Wermer* \\ Savannah River Technology Center \\ Westinghouse Savannah River Company \\ Aiken, SC 29808 \\ * Current Address \\ Los Alamos National Laboratory \\ Los Alamos, NM
}

50 weight \% $\mathrm{Pd}$ on kieselguhr $(\mathrm{Pd} / \mathrm{k})$ is used in hydrogen isotope separation processes at the Savannah River Site. Long term aging studies on this material were undertaken in June 1992. P-c-T data showing the aging effect of tritium loading for long periods will be presented and discussed covering from June 1992 to March 1998. Lowering of plateau pressures and increasing indications of inhomogeneities have been observed in both tritium and deuterium absorption isotherms at $0 \mathrm{C}$, and desorption isotherms at 80 and $120 \mathrm{C}$.

\section{Introduction}

The Savannah River Site (SRS) is a U.S. Department of Energy-owned facility involved in part in hydrogen isotope separation operations. Metal hydrides figure prominently in those processes (1-4). The primary hydrogen isotope of interest to SRS is tritium. Tritium decay is known to induce aging affects in metal hydrides (5-10) which are thought to arise primarily because of structural changes in the hydride caused by the deposition and migration of the ${ }^{3} \mathrm{He}$ tritium decay product. In general the changes induced by aging (lowering of plateau pressure, increased inhomogeneity, decreased capacity) are deleterious and the desire is to avoid them if possible.

One particular metal hydride material used at SRS is 50 weight percent palladium supported on kieselguhr $(\mathrm{Pd} / \mathrm{k})$. Kieselguhr is a diatomaceous earth (primarily silicon dioxide based) commonly used as a catalyst support. Depositing Pd on the kieselguhr was expected to spread it out producing a higher surface to volume ratio, which would promote ${ }^{3} \mathrm{He}$ release and mitigate aging effects. In order to experimentally investigate this proposition, the research facility at SRS, the Savannah River Technology 
Center (SRTC), placed three samples of different Pd/k types into a longterm study of tritium aging effects.

One $\mathrm{Pd} / \mathrm{k}$ sample was taken from actual process material. This material had originally been prepared by thermally treating $\mathrm{PdCl}_{2}$-saturated kieselguhr, but the as-prepared material was found to have a high chloride content. This material had to be further heat-treated for several hours at $1100{ }^{\circ} \mathrm{C}$ to reduce the $\mathrm{Cl}$ content. This material then became the base process material. A sample of the as-received material was also placed into the study. A third sample was taken from a $\mathrm{Pd} / \mathrm{k}$ prepared by thermally decomposing $\left(\mathrm{NH}_{3}\right)_{4} \mathrm{Pd}\left(\mathrm{NO}_{3}\right)_{2}$ absorbed on kieselguhr. This material was called 'improved' $\mathrm{Pd} / \mathrm{k}$ because the process was a non-chloride one, and thus chloride corrosion problems could be avoided.

Select virgin samples were investigated by $\mathrm{H}_{2}, \mathrm{D}_{2}$, and $\mathrm{T}_{2}$ isotherm determination and then loaded to $\mathrm{T} / \mathrm{Pd}$ ratios of $\sim .65$. Those samples were then placed in storage at room temperature for 2-3 years, at which time they were reinvestigated in order to determine aging effects. Subsequently, they were reloaded and again stored for 2-3 years. In brief, the virgin material behavior is very similar to that of bulk palladium powder. However the different $\mathrm{Pd} / \mathrm{k}$ samples do exhibit different aging characteristics. This paper presents the results obtained by investigations conducted on samples aged for $\sim 2$ and $\sim 5$ years.

\section{Experimental}

SRTC has two facilities for studying metal hydride chemistry. One is equipped with several stainless steel gas-handling manifolds for isotherm determination with non-radioactive hydrogen isotopes. The second facility is designed to handle tritium, and has two linked manifolds for radioactive work enclosed in an air-hood and operated through gloveports. System pressures are limited to less than 182 psia, although actual operating pressures are usually lower. Tritium is supplied from $\mathrm{a} \mathrm{LaNi}_{4} \mathrm{Al}_{5}$ bed. Both facilities use Nupro valves and Cajon metal-to-metal connections.

Stainless steel sample holders used in this study are horizontal beds approximately 3-4 inches long and 3/4" in diameter (9). These have either a dual thermocouple welded into the vessel such that the thermocouple tip is located in the sample, or a thermocouple well similarly placed. Two Nupro 
valves are mounted on a vertical tube located on one side of the bed and are used to connect to the manifolds via Cajon VCR-4 type connections.

Pressures are normally measured with 10,000 torr MKS Baratron pressure sensors that have been calibrated in the SRS Standards Laboratory to NIST traceable standards. Sample sizes and designations are: 'as-received' (labeled PDK1), 7.3 g 55wt\% Pd/k; 'process' (labeled PDK2), 7.3 g 51 wt\% $\mathrm{Pd} / \mathrm{k}$; 'improved' (labeled PDK3), $3.5 \mathrm{~g} 55 \mathrm{wt} \% \mathrm{Pd} / \mathrm{k}$; process (labeled $\mathrm{PDK} 4), 53.1 \mathrm{wt} \% \mathrm{Pd} / \mathrm{k}$ (used for additional virgin material studies). The primary $\mathrm{Pd} / \mathrm{k}$ samples (PDK1, 2, \&3) were originally loaded and studied in mid-1992. Properties were redetermined in mid-1995 and again in mid-1997 (PDK2) and early to mid-1998 (PDK1 and 3).

As received $\mathrm{Pd} / \mathrm{k}$ wàs prepared by saturating kieselguhr with $\mathrm{PdCl}_{2}$ and then heat treating in the presence of ammonia and hydrogen at $3-400{ }^{\circ} \mathrm{C}$ for as many cycles as required to obtain the desired weight percent $\mathrm{Pd}$. The number of cycles can vary from as few as 8 to as many as 30 for 55 weight percent $\mathrm{Pd}$ material. Process $\mathrm{Pd} / \mathrm{k}$ was as received $\mathrm{Pd} / \mathrm{k}$ heated in air at 1100 ${ }^{\circ} \mathrm{C}$ for 2 hours. Improved $\mathrm{Pd} / \mathrm{k}$ is kieselguhr loaded with $\left(\mathrm{NH}_{3}\right)_{4} \mathrm{Pd}\left(\mathrm{NO}_{3}\right)_{2}$ and heat treated in air at $2-300{ }^{\circ} \mathrm{C}$ to decompose the nitrate for as many cycles as required to obtain the desired weight percent $\mathrm{Pd}$.

\section{Results and Discussion}

Figure 1 shows tritium desorption isotherms acquired at $80^{\circ} \mathrm{C}$ with the three $\mathrm{Pd} / \mathrm{k}$ samples and a pure $\mathrm{Pd}$ powder. Differences are very minor, with a slight plateau pressure elevation noted for the $\mathrm{Pd} / \mathrm{k}$ samples as opposed to $\mathrm{Pd}$ powder. The process $\mathrm{Pd} / \mathrm{k}$ sample seems to have a 'heel' in that the terminal $\mathrm{T} / \mathrm{Pd}$ value obtained is not zero. In aged samples, a heel is an expected phenomenon and isotope exchanges are conducted to analytically determine its size. Unfortunately, such a determination was not conducted on the virgin materials. In aged samples, heels are determined and isotherms are adjusted to the determined values.

Table $1 .{ }^{3} \mathrm{He}$ detected in gas phase (as \% of total)

\begin{tabular}{|l|l|l|l|}
\hline Sample & PDK1 & PDK2 & PDK3 \\
\hline Age at sampling (years) & 2.3 & 2.3 & 2.2 \\
\hline \% of Total Generated & 10 & 4 & 24 \\
\hline Age at sampling (years) & 5.8 & 5.1 & 5.8 \\
\hline
\end{tabular}


Table 1 presents results on ${ }^{3} \mathrm{He}$ release. The release data is determined by sampling the overpressure at the end of the storage period and analyzing with mass spectrometry. Gas phase ${ }^{3} \mathrm{He}$ in excess of that born in the overpressure has been released from the solid. In contrast to expectations, the as-received and process $\mathrm{Pd} / \mathrm{k}$ samples do not show the expected enhanced ${ }^{3} \mathrm{He}$ release that can be observed in improved $\mathrm{Pd} / \mathrm{k}$. The enhanced release rate of improved $\mathrm{Pd} / \mathrm{k}$ suggests we could expect to see less severe aging effects in that material, and this is observed. The process $\mathrm{Pd} / \mathrm{k}$ behaves most similarly to bulk Pd powder, and its tritium isotherms are shown in Figure 2 (desorption isotherms are shown for 80 and $120^{\circ} \mathrm{C}$, absorbtion isotherms are shown at $0{ }^{\circ} \mathrm{C}$ ). As can be seen, there is a . progressive depression of the plateau pressures with sample age and an increase in plateau sloping in the lower T/Pd regions. The major capacity decrease of about $0.05 \mathrm{~T} / \mathrm{Pd}$ units is observed to occur during the first aging period, with only minor changes noted from the second period in agreement with the literature (5). The difference in fact was within experimental error, and thus all aged desorbtion isotherms are forced to a terminal T/Pd value of 0.05 . Virgin material isotherms at 0 and $120^{\circ} \mathrm{C}$ on this Figure were obtained with PDK4. The virgin $80^{\circ} \mathrm{C}$ data represents 3 sequential isotherms and illustrate good experimental reproducibility.

Figure 3 presents $120^{\circ} \mathrm{C}$ isotherms for all the $\mathrm{Pd} / \mathrm{k}$ samples, which graphically show the expected lesser aging of improved $\mathrm{Pd} / \mathrm{k}$. Also of note is the fact that the process $\mathrm{Pd} / \mathrm{k}$ shows the largest amount of plateau pressure depression and sloping. This can probably be traced to the morphological effects of heat treatments. The order of increasing heat treatment severity is process $>$ as-received $>$ improved, which correlates with the increasing evidence of aging (more heat implies more depression and sloping and less He release). Some duplicate runs were conducted but they did not show much variation, leading us to conclude that aging effect 'healing' observed in other hydride materials (9) was not significant in our experiments. Clearly some morphological effect is active in these samples, as has been noted elsewhere in similar materials (11).

We have also taken the step of comparing our results with those of other researchers. Lasser (6) has published Pd-T isotherm data, which we reproduce in Figure 4. Overlaid on this data is the SRS data obtained at similar temperatures on several samples. The range spanned by the $80^{\circ} \mathrm{C}$ 
SRS data represents sample type and aging effects, and the virgin asreceived $\mathrm{Pd} / \mathrm{k}$ agrees well with Lasser's data. Additionally, we have used van't Hoff parameters (6) to calculate expected plateau pressures and find that our data agree reasonably well. We have also compared to data published by Wicke (13) as shown in Figure 5. In this case the SRS data also agree well with the published data. It should be noted that these comparisons further illustrate the fact that virgin $\mathrm{Pd} / \mathrm{k}$ behaves essentially as bulk Pd powder.

\section{Summary}

In conclusion, we have shown that virgin $\mathrm{Pd} / \mathrm{k}$ behaves essentially as $\mathrm{Pd}$ powder. Further, as tritium decays inside the materials, aging effects are produced that correlate with those observed in aging Pd-T systems. We have also illustrated the apparent inverse correlation of aging effect magnitude and initial heat treatment. Future work will hopefully illuminate this effect more fully.

\section{Acknowledgement}

This work was supported under DOE contract Number DE-AC0988SR18035. D. R. Bell, W. Britt, D. Mosely, R. Stanley, and C. Wilkins were instrumental in acquiring data. The authors gratefully acknowledge helpful discussions with Prof. T. Flanagan, U. Vermont.

References

1. M. S. Ortman, L. K. Heung, A. Nobile, and R. L. Rabun III, J. va. Sci. Technol., A8(3) (1990) 2881, and references therein.

2. A. Nobile, Jr., Fusion Tech., 20 (1991) 186 and references therein

3. A. S. Horen and M. W. Lee, Fusion Tech., 21(2) pt. 2 (1992) 282

4. T. Motyka, Fusion Tech., 21(2) pt. 2 (1992) 247

5. S. Thiebaut, V. Paul-Boncour. A. Percheron-Guegan, B. Limacher, O. Blaschko, C. Maier, C. Talland, and D. Leroy, Phys. Rev. B 57(17) (1998) 10379 
6. R. Lasser, "Tritium and Helium-3 in Metals", Springer Series in Materials Science 9, Springer-Verlag, 1989, ISBN 3-540-19056-2 or 0387-19056-2, and references therein

7. G. C. Abell, L. K. Matson, R. H. Steinmeyer, R. C. Bowman, Jr., B. M. Oliver, Phys. Rev. B 41(2) (1990) 1220

8. J. A. Emig, R. G. Garza, L. D. Christensen, P. R. Coronado, and P. C. Souers, J. Nucl. Materials, 187 (1992) 209

9. R. T. Walters, J. Less-Common Metals, 157 (1990) 97

10. A. Nobile, Jr., R. T. Walters, and W. C. Mosley, Proc. Of the Int'1 Symp. On Metal-Hydrogen Systems Fundamental and Applications, Banff, Canada, (1990), published in J. Less-Common Metals, 172-174 (1991), 1352

11.P. Chou and M. A. Vannice, J. Catal. 104 (1987) 1

12. E. Wicke and H. Brodowsky in "Hydrogen in Metals II, ApplicationOriented Properties", Topics in Applied Physics Volume 29, ed. G. Alefeld and J. Volkl, (1978), p. 81, Springer-Verlag, ISBN 3-540-088830 or $0-387-08883-0$, and references therein 
Figure Captions

Figure 1. Comparative $80^{\circ} \mathrm{C}$ tritium desorption isotherms for virgin $\mathrm{Pd}$ powder and $\mathrm{Pd} / \mathrm{k}$ samples, illustrating the general agreement of virgin $\mathrm{Pd} / \mathrm{k}$ with Pd powder.

Figure 2. Process $\mathrm{Pd} / \mathrm{k}$ (PDK2) tritium 80 and $120^{\circ} \mathrm{C}$ desorption, and $0{ }^{\circ} \mathrm{C}$ absorption isotherms for virgin and aged sample. The $120^{\circ} \mathrm{C}$ virgin isotherm is from sample PDK4. The three $80^{\circ} \mathrm{C}$ virgin material isotherms illustrate good reproducibility.

Figure $3.120^{\circ} \mathrm{C}$ desorption isotherms from aged and virgin $\mathrm{Pd} / \mathrm{k}$ samples, illustrating the decreasing plateau pressures and increased plateau sloping observed in aged samples. (Note: Aged isotherms forced to $\mathrm{T} / \mathrm{M}=0.05$ )

Figure 4. Palladium-tritium desorption isotherms. Comparison of SRS data for virgin $\mathrm{Pd} / \mathrm{k}$ and virgin and aged Pd powder to that of Lasser (6). (Lasser's data from his ref. 5.55, converted to torr.) Also shown is an isotherm from Pd powder that had been aged for 5 years.

Figure 5. Palladium-hydrogen desorption isotherms. Comparison of SRS data for virgin improved $\mathrm{Pd} / \mathrm{k}$ to that of Wicke and Brodowsky (12) for Pd. (Note: Wicke and Brodowsky's Figure 3.4 was scanned and digitized to get the data. Higher temperature $\left(>160^{\circ} \mathrm{C}\right)$ curves not shown.) 
Figure 1.

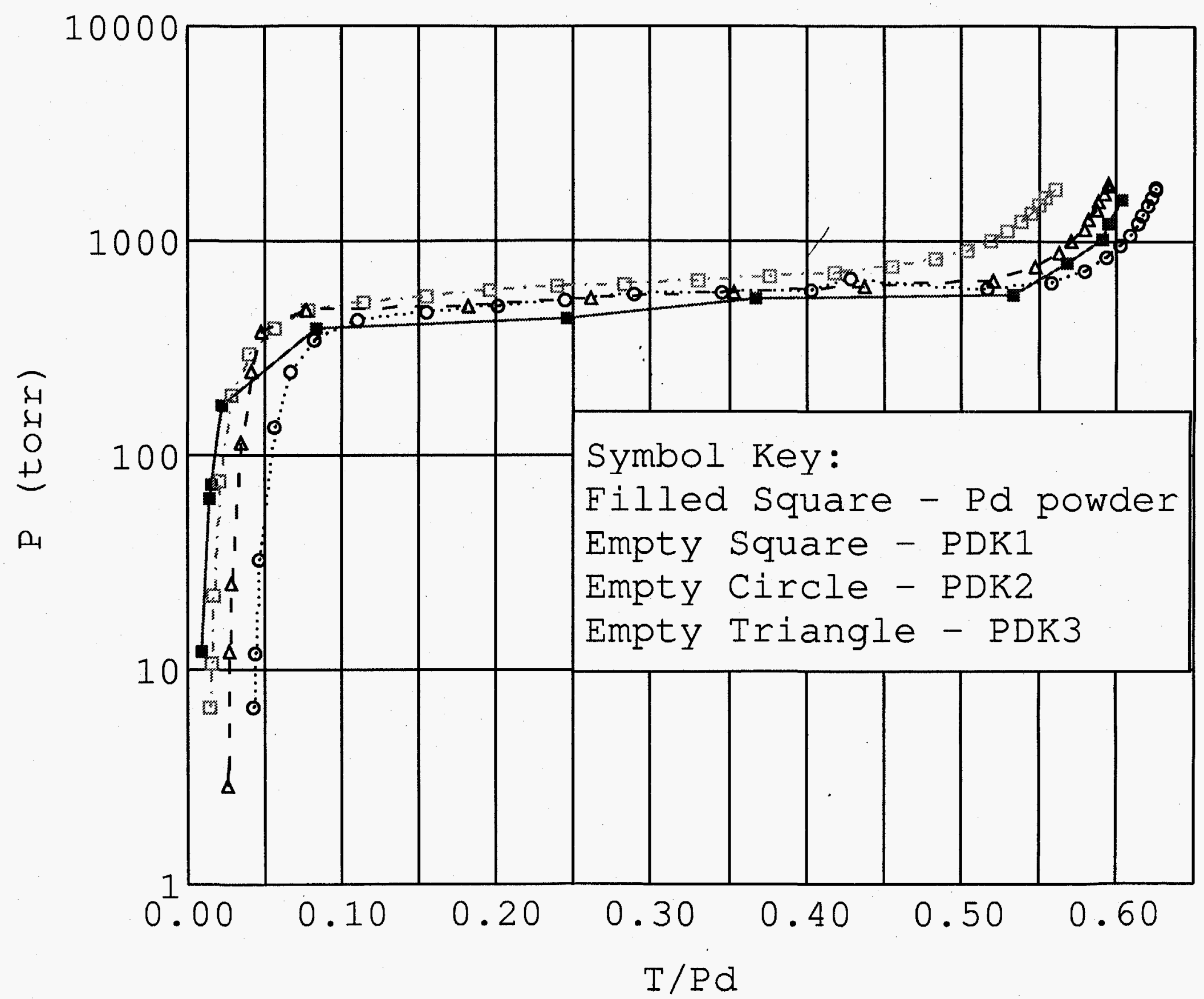




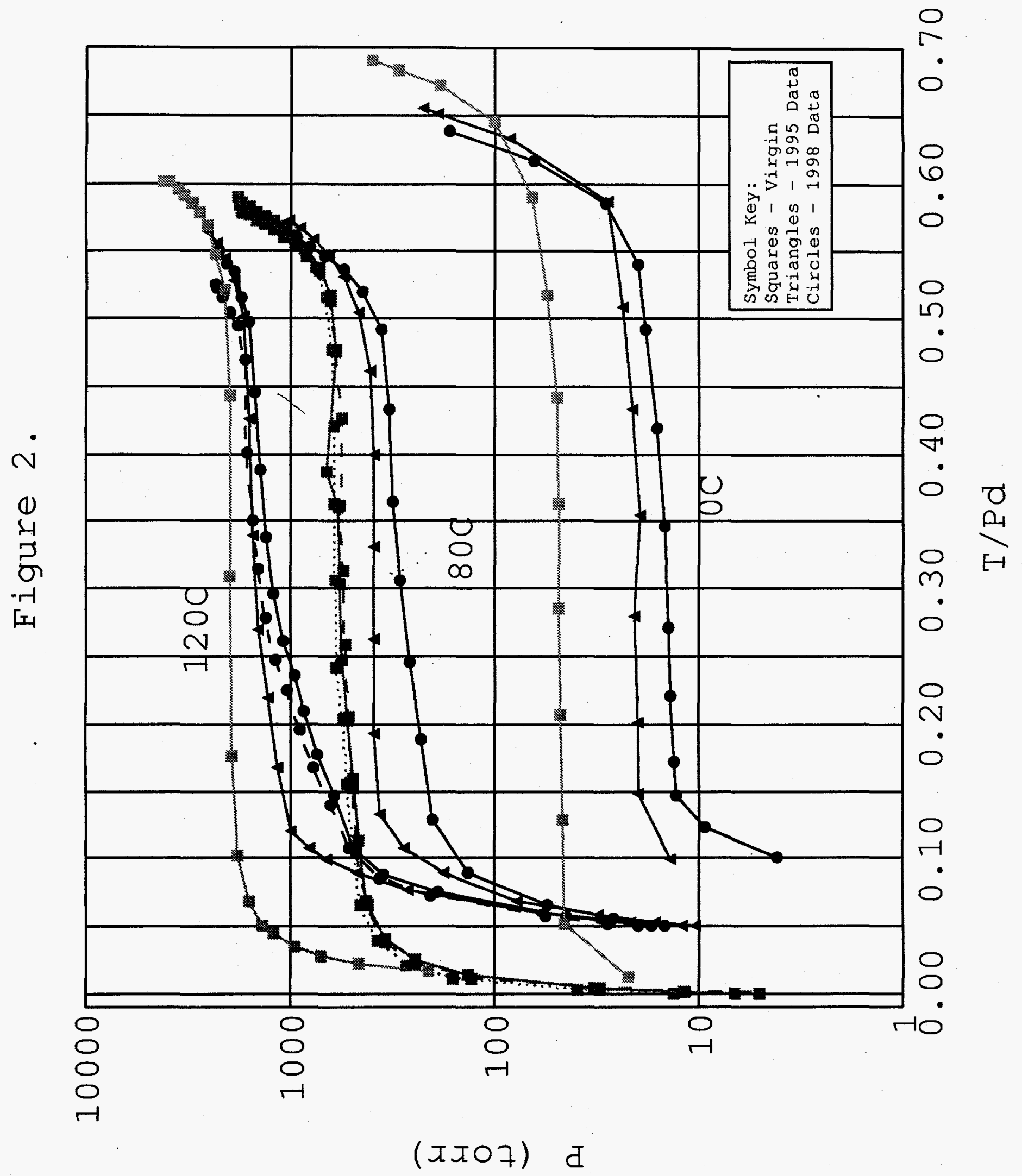


Figure 3 .

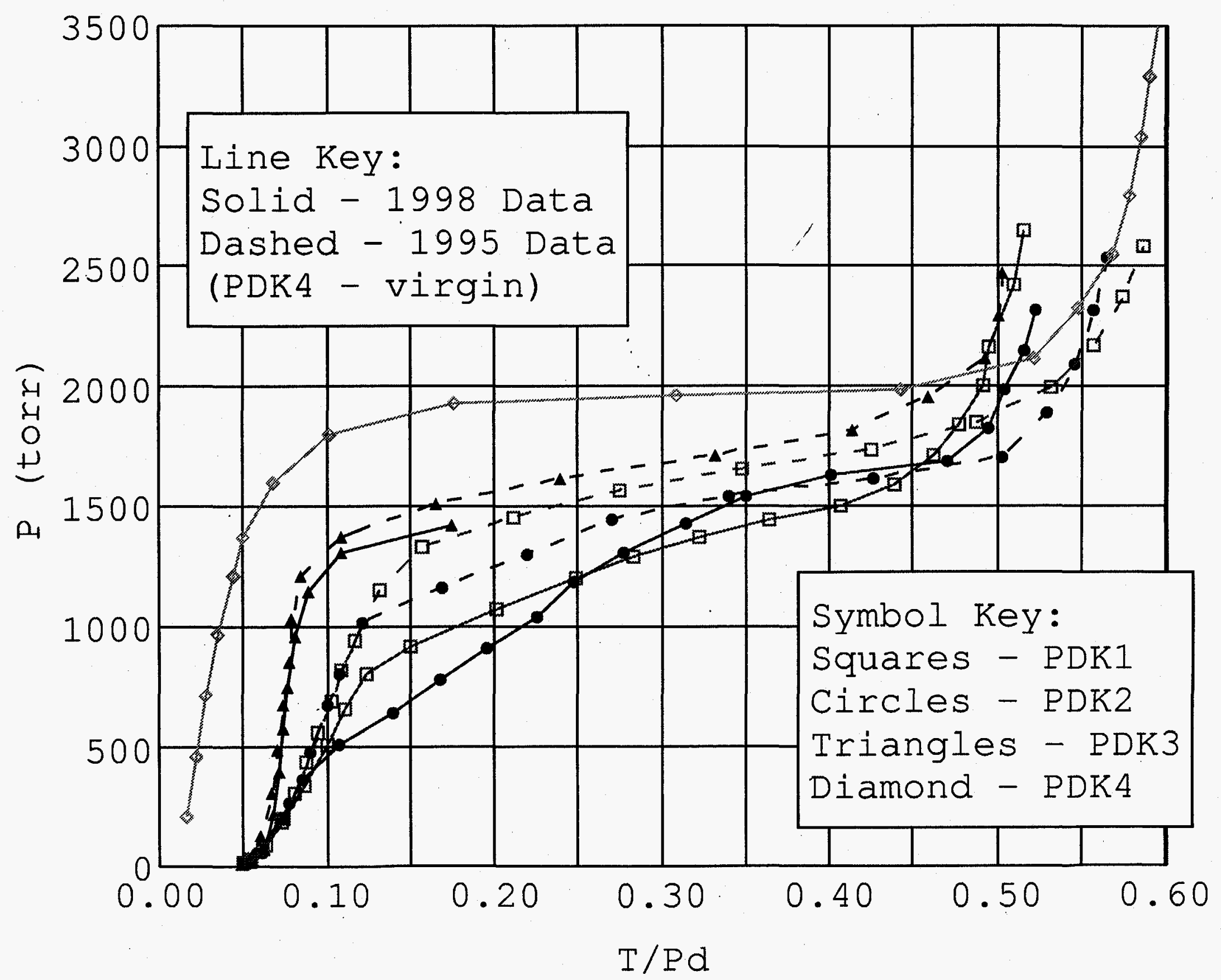




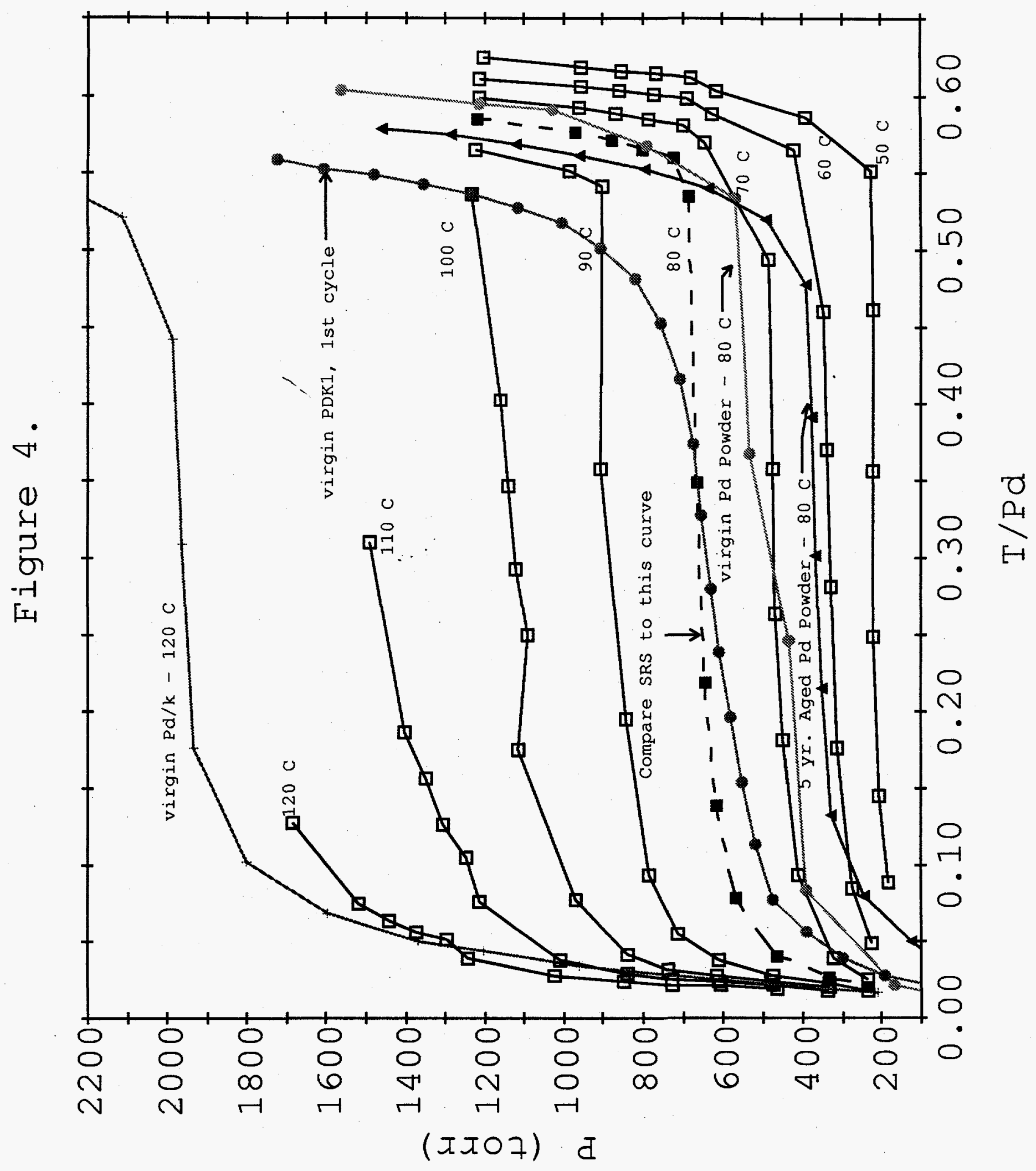




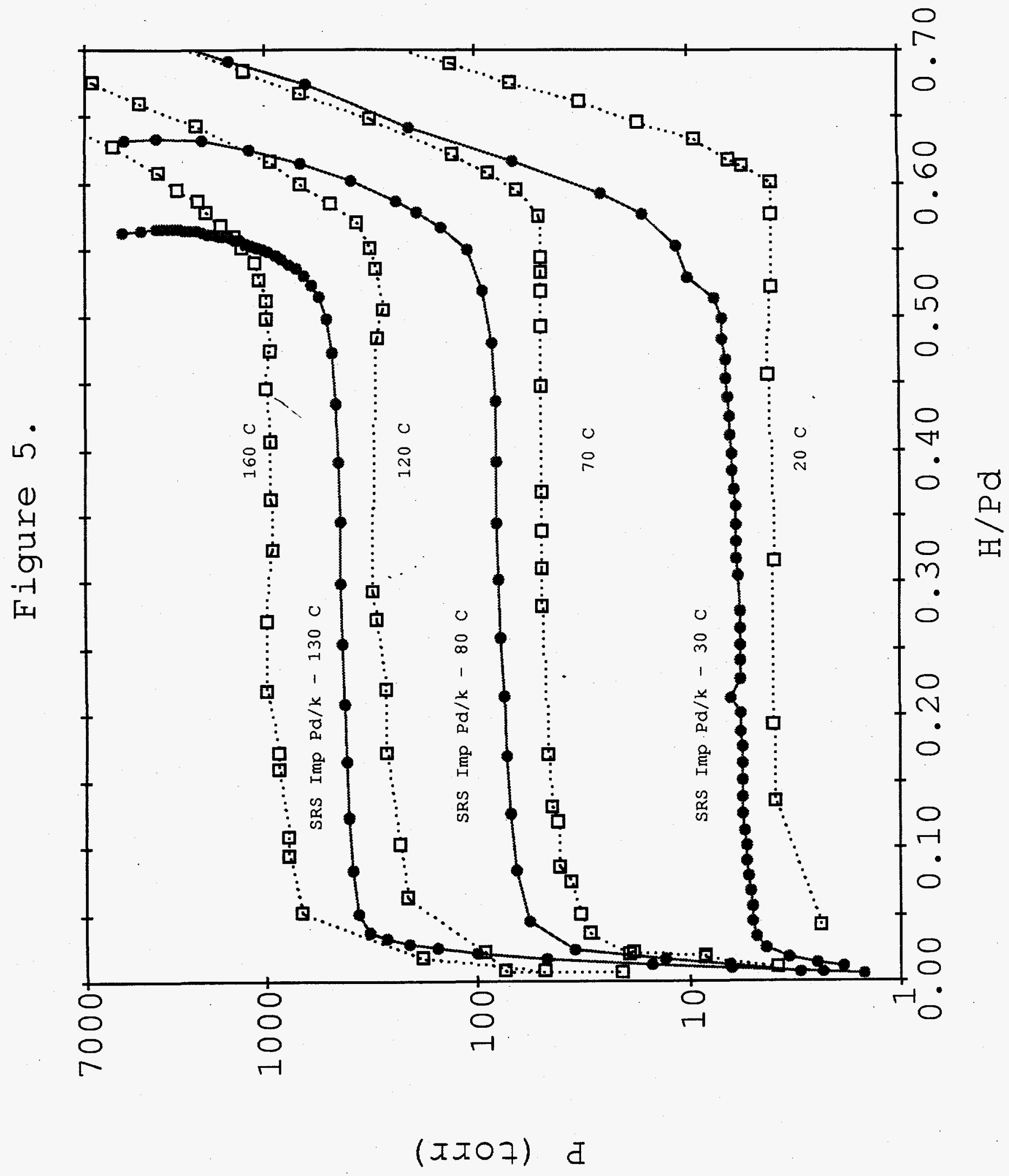

